\title{
State of research on public service management: Identifying scientific gaps from a bibliometric study
}

\author{
Fernando Juliani*, Otávio José de Oliveira \\ Production Engineering Department, São Paulo State University, Av. Ariberto Pereira da Cunha, 333, Portal das Colinas, 12516-410, Guaratinguetá, São \\ Paulo, Brazil
}

\section{A R T I C L E I N F O}

\section{Article history:}

Received 8 January 2016

Accepted 8 July 2016

Available online 16 July 2016

\section{Keywords:}

Public service management

Bibliometric study

State of research

Scientific gap

\begin{abstract}
A B S T R A C T
Academic interest in aspects of the public sector has grown considerably, especially in the areas of social sciences, management and finance. In the studies that are specifically designed to public service management, this growth was herein observed and analyzed.

The current paper presents and analyses major publications involving public service management in the decade of 2004-2014, so as to identify scientific gaps to promote and guide new studies on the aforementioned subject. For this purpose, a bibliometric study of related scientific papers was carried out. The data was collected from the Scopus and Web of Science databases, enabling an analysis of the most cited articles, keywords and authors, and of the most recently published article on public service management by each of these cited authors. Based on this analysis, it was observed that the New Public Management model is the principal object of research on public service management, and that the scientific gaps mainly involve the public service motivation. In this way, the main scientific contribution of the present paper is to assist new studies on public service management, including the expansion of existing theory and innovative model proposals.
\end{abstract}

() 2016 Elsevier Ltd. All rights reserved.

\section{Introduction}

Globalization has had a great impact on public service management and compelled managers to be increasingly agile at adopting practical solutions to unforeseen problems, such as economic crises, epidemic diseases and environmental problems. These events coupled with domestic political issues like public transport, information management and security have generated demands for private sector solutions and originated global perspectives for building up knowledge in the public sector (Hou, Ni, Poocharoen, Yang, \& Zhao, 2011).

A large part of public services is provided by local governments, and inefficiencies in the execution of these services can generate serious consequences for the social welfare of citizens (Cuadrado-Ballesteros, García-Sánchez, \& Prado-Lorenzo, 2012). However, meeting the expectations about the services provided by a public organization does not only depend on the organization itself, but on multiple governmental and non-governmental actors (Hall, 2007).

\footnotetext{
* Corresponding author.

E-mail addresses: frdjuliani@gmail.com (F. Juliani), otaviodeoliveira@uol.com.br (O.J. de Oliveira).
}

The search for solutions to problems that are characteristic of the public sector has aroused great interest from researchers and managers in assessing the quality of public service and governance processes, and also the life quality of the people under the influence of such type of service (Gonzalez, Carcaba, Ventura, \& Garcia, 2011). According to Hou et al. (2011), it is necessary that the knowledge about the activities of public management is spread throughout various contexts and that it is not restricted to the analysis of specific cases.

The number of studies aimed at the New Public Management model (NPM), public service motivation (PSM), public sector organizations, performance, governance, ethics, local governments, job satisfaction, public sector reform and innovation have increased considerably in the period analyzed in this work (2004-2014), encouraging discussions on the factors that interfere with the quality of services provided by public organizations. The knowledge generated by these studies enables the identification of scientific gaps and assists new researches covering both the expansion of existing theory and the proposition of innovative models related to public service improvement.

In light of the above, this bibliometric study presents and analyses major publications involving public service management in the decade of 2004-2014, so as to identify scientific gaps to promote and guide new studies on the subject, allowing and encouraging 
that its findings should be adopted by public service organizations worldwide.

The following section gives an overview over the theory on which this work was based. Subsequently, the research method used in this article is presented, covering the adopted research parameters, databases and computational tools used in its analysis. After that, the results obtained are described and analyzed in order to systematize the scenario of the publications on the topic and to identify gaps. In the last section, the findings of the study are presented, highlighting their scientific contribution and proposals for future studies.

\section{Theoretical overview}

Public service management comprises interdisciplinary knowledge of economics, sociology, organizational theory and law, which should be integrated with characteristic elements of the public sector as motivation, bureaucracy and governance (Voet, 2014). The study of public organizations encompasses academic disciplines such as political science, psychology and business management, which are aimed at understanding the structure, culture, processes, technologies, environments and change management of the sector (Soni, 2011).

According to Motta (2013), the concept of efficient public management has evolved with the Industrial Revolution and the weakening of the aristocratic and absolutist powers. In the early 20th century, there was a search for universal principles of public management that resulted in excessive focus on control mechanisms. In the second half of the century, it was sought to separate the political aspects of administration through the creation of the New Public Administration.

The idea of managing public organizations in an analogous way to private organizations was disseminated in the last decades of the 20 th century with a promising management model, the NPM, which emerged with the main purpose of running public organizations as private companies that are aimed at generating profits, i.e. with process efficiency, cost reduction and efficiency in the provision of services (Motta, 2013). At the beginning of the 21st century, governments were more concerned about ensuring that public services were conducted effectively, and so began to delegate their authority to third parties, where governance became one of the most applied tools in public service management (Soni, 2011).

In the view of Peters, Pierre, and Randma-Liiv (2011), it has been part of the logic of governance to decompose the public sector into numerous organizations for specific purposes in order to increase efficiency in the provision of services. That logic, however, leads to a division of regulatory powers and information, thus limiting the ability of the public sector to improve its financial management, to innovate and to make systemic improvements. Furthermore, public organizations vary in function, structure and administrative level (Lindgren \& Jansson, 2013) and have been under direct influence of the political system since the beginning of their history until the present day.

According to Conteh (2012), one of the greatest challenges of public sector is to institutionalize new mechanisms of political participation that support the practice of governance in its various organizational levels. Nevertheless, the public service management is conducted by order-oriented principles and practices, uniformity and fairness, which depend to a great extent on political consensus and support (Motta, 2013).

Therefore, there are specific constraints and pressures in the public sector that create a more complex context when compared to private companies' environment, thus increasing the number of related studies, such as the NPM model (Garrett \& Sementelli, 2012), PSM (Wright, Christensen, \& Isett, 2013), per-

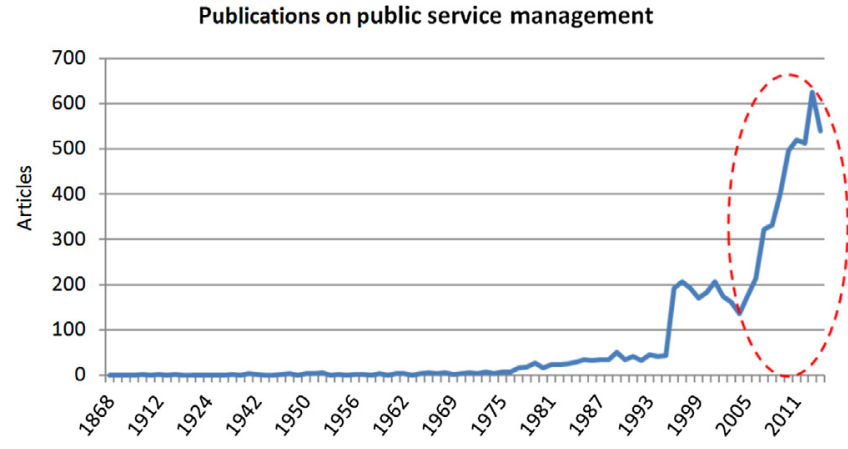

Fig. 1. Number of articles on public management published from 1868 to 2014 with emphasis on the evolution in the latest decade (data extracted from the Scopus database).

formance (Walker, Brewer, Boyne, \& Avellaneda, 2011) and public service organizations (Rashman, Withers, \& Hartley, 2009), as it is going to be addressed subsequently in this manuscript.

\section{Research method}

The present study was based on a bibliometric analysis of articles on public service management that were published and peer-reviewed between 2004 and 2014 in major scientific journals, in order to characterize and analyze their knowledge, and also to identify gaps so as to guide new scientific studies aimed at public management improvement.

The research was conducted by means of queries on the Web of Science (WoS) and Scopus databases, which provide access to scientific articles published in the following journals, among other publishers: Elsevier (www.sciencedirect.com), Emerald (www.emeraldinsight.com), Springer (www.springerlink.com), Wiley (www.wiley.com). Items of information from both databases were used for different analyses in this study, as illustrated in Table 1.

The first search filter utilized in the research was regarding the articles' title, where terms that characterized the topic "public service management" were used. This filter was adopted to reduce search time and increase the results' accuracy.

It was considered that the study of articles published in 2004-2014 would enable the acquisition of knowledge about the stage of research on public service management and the identification of trends in a period in which a sharp growth in the number of articles published on the topic was observed, as illustrated in Fig. 1.

The search was restricted to documents named "articles" due to the understanding that they enable a better and more reliable identification of scientific gaps relating to the topic "public service management", than the analysis of "reviews", "chapters", "books" and "editorials". The search filters used in this research and the number of resulting articles respectively, are shown in Table 2.

At an initial search, it was observed that a large number of articles resulting from the search carried out on the databases of WoS (2628 articles, considering all areas) and Scopus (4280 articles, considering all areas) exceeded the scope of this work because they were related to areas such as social sciences, economics and medicine, as illustrated in Fig. 2. The search was limited to articles that were related only to the areas of management (public administration, business, management and accounting), which resulted in 1148 articles in WoS and 1706 in Scopus, as shown in Table 2. This difference in number of articles can be explained by the different classifications adopted in each of the databases, which is also observed in the works conducted by Abrizah, Zainab, Kiran, and Raj (2013) and Bartol, Budimir, Dekleva-Smrekar, Pusnik, and Juznic (2014). 
Table 1

Databases used in different types of analyses.

\begin{tabular}{|c|c|c|}
\hline & \multicolumn{2}{|l|}{ Databases } \\
\hline & WoS & Scopus \\
\hline Analyses & $\begin{array}{l}\text { - Citations of the most cited authors } \\
\text { - Publications of the most cited authors } \\
\text { - H-index of the most cited authors } \\
\text { - Citation network of the most cited authors }\end{array}$ & $\begin{array}{l}\text { - Most used keywords } \\
\text { - Most cited articles } \\
\text { - SJR value of journals } \\
\text { - Institutions of the most cited authors } \\
\text { - Last article published by the most cited authors } \\
\text { - Gaps identified by the most cited authors }\end{array}$ \\
\hline
\end{tabular}

Table 2

Search filters used in the research.

\begin{tabular}{|c|c|c|}
\hline \multirow[t]{2}{*}{ Search fields } & \multicolumn{2}{|l|}{ Databases } \\
\hline & WoS & Scopus \\
\hline Article title & $\begin{array}{l}\text { "public administration" or "public management" or "public } \\
\text { sector" or "public service" }\end{array}$ & $\begin{array}{l}\text { "public administration" or "public management" or "public } \\
\text { sector" or "public service" }\end{array}$ \\
\hline Period & $2004-2014$ & $2004-2014$ \\
\hline Subject area & Public administration & Business, Management and Accounting \\
\hline Language & English & English \\
\hline Document type & Article & Article \\
\hline Results & 1148 & 1706 \\
\hline
\end{tabular}

\title{
Articles by subject areas
}

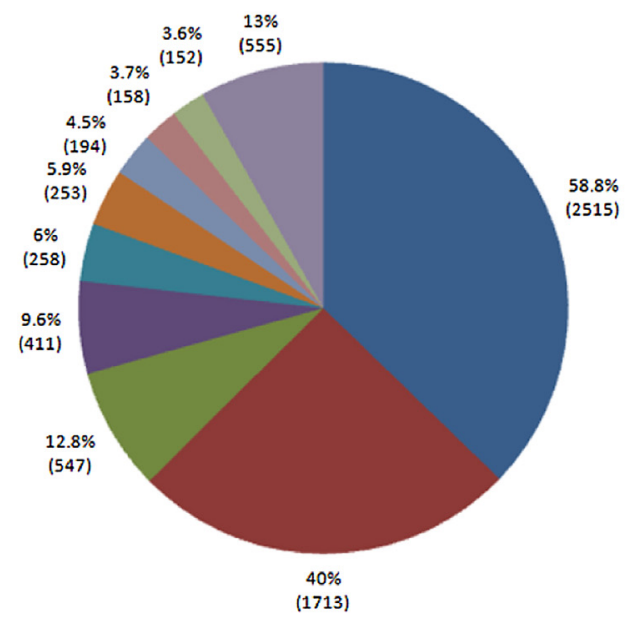

\author{
nocial Sciences \\ a Business, Management and Accounting \\ Economics, Econometrics and Finance \\ aedicine \\ - Computer Science \\ nEnvironmental Science \\ Engineering \\ Arts and Humanities \\ Decision Sciences \\ Others
}

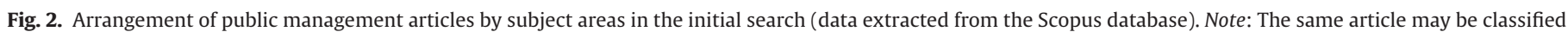
in more than one area, therefore the sum of the percentage results in more than $100 \%$.

The bibliometric analysis of the data was carried out with the support of the computational tools Sci2 and Microsoft Excel. The Sci2 tool enabled the analysis of data extracted from the WoS database and provided information about the number of citations and the authors' network. The Microsoft Excel spreadsheet enabled the analysis of the most cited keywords extracted from the Scopus database and assisted in the preparation of tables and charts based on the information extracted from both databases, encompassing the most addressed topics and the recently published works by the most cited authors.

The frequency of incidences of keywords in the studied articles allowed identifying what were the most addressed topics on the theme of "public service management". It should be noted that the keywords which are similar to those used as inputs for the search were disregarded in order to not compromise the analysis. Finally, in the case of articles from journals that do not use keywords (Public Administration Review, Journal of Public Administration Research and Theory, Public Administration, and International Public Manage- ment Journal), it was sought to review the titles of these articles and identify terms or expressions that define the addressed topic in the manuscript, as suggested by Gil-Leiva and Alonso-Arroyo (2007).

The process of identifying scientific gaps on the topic "public service management" was conducted by analyzing the suggestions for future studies in each of the ten most cited authors' latest articles. This criterion aimed at increasing the degree of originality of the gaps due to a shorter time of the latest publication in comparison with that of the most cited article.

\section{Bibliometric analysis}

According to Gomez-Jauregui, Gomez-Jauregui, Manchado, and Otero (2014), the bibliometric analysis allows developing knowledge about the impact of a particular research area, the influence of research groups or institutions, the scientific impact of a publication or the academic results of quantitative research. On the other hand, Vogel (2013) claims that the bibliometric analysis aims pre- 
Most cited keywords (2004-2014)

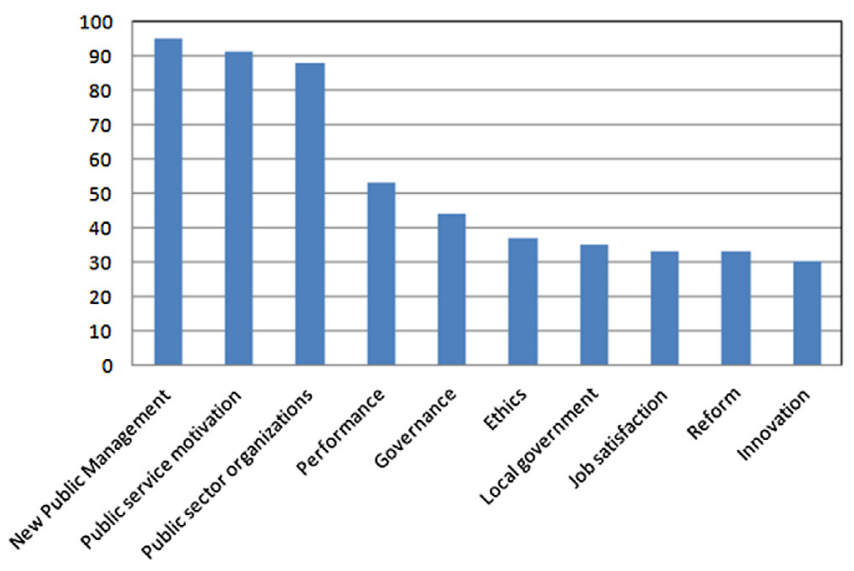

Fig. 3. Histogram with the ten most frequently used keywords.

cisely at clarifying the relation between different areas of study. Hsiao and Yang (2011) consider it is possible to map a research area and to broaden knowledge about it with the establishment of a connection pattern between the main publications.

The review of the state of research and the identification of scientific gaps on "public service management" were performed by extracting the data from WoS and Scopus. This data was processed and normalized, and the resulting information allowed a consistent analysis of the most cited articles, keywords and authors, and of the most recently published article about public service management by each of these cited authors. The first three analyses are focused on characterizing the research on the topic, while the last one concentrates on the identification of the scientific gaps.

\subsection{State of research on public service management in the decade of 2004-2014}

According to Ercan and Cicekli (2007), keywords are concise representations of a given text, which allow readers to identify its relevance in advance. In order to characterize the status of publications on public service management in the decade of 2004-2014, an analysis of the most cited keywords was carried out, which led to the identification of what were the most addressed topics on the subject. The search resulted in the keyword "New Public Management" as being the most commonly found in the studied scientific articles, comprising approximately 5.5\% (95 articles) of the total amount, as shown in Fig. 3. The second most commonly found keyword was "public service motivation", which resulted in approximately 5.3\% (91 articles), thus being the most commonly used keyword from 2012 to 2013, as illustrated in Fig. 4. The third most commonly found keyword was "public sector organizations" with approximately $5.1 \%$ ( 88 articles), which was most frequently used during the periods of 2005-2007 and 2009-2010.

The keyword "performance", although only being the fourth most commonly cited keyword (53 articles), should have its importance highlighted by the fact that the terms related to the same subject, such as "performance management" (30 articles), "performance measurement system" (21 articles) and "performance measures" (11 articles) also appear among the most frequently used keywords in scientific articles. In addition, the fact of "public sector performance" being the most addressed topic by many of the researchers with the highest number of citations, confirms it as being one of the most important research topics in the area of public service management. This will be presented and analyzed later in this article.
The characterization of articles on public service management proceeded with the analysis of the ten most cited articles in this period. It was observed that "public service motivation" was the most discussed topic, confirming it as being one of the most researched issues and, consequently, one of the most relevant ones. The other ones cover public sector aspects, such as co-production (approach in which it is assumed that users participate in the planning and provision of services offered to them) (Bovaird, 2007), reform, change, shared services, values, organizations, contracts and accounting, as illustrated in Table 3.

Taking into account the keywords shown in Fig. 4, it should be noted that the topics "NPM" and "public service performance" are not present in the most cited articles presented in Table 3. It should also be highlighted that the ten most cited articles are comprised between 2004 and 2008, which suggests a greater number of citations of articles that were published six years or longer ago.

With regard to journals in which the most cited articles were published, it was observed that the "Public Administration Review" contains six of the ten most cited articles and the "Journal of Public Administration Research and Theory" contains two of the ten most cited articles. Based on the SCImago Journal Rank (SJR) indicator proposed by Guerrero-Bote and Moya-Anegón (2012), that it takes into account the prestige of the citing scientific journal and its closeness to the cited journal, these journals have SJR values of 1.59 and 3.67 respectively, thus having a considerable scientific impact in the international community. The former's main objective is to identify and analyze trends in public service management and to provide a basis for decision-making, while the latter has a multidisciplinary character which aims at contributing to the advancement of political, managerial and organizational sciences.

It should be highlighted that a general evolution pattern was not recognized in the number of citations analyzed in Table 3, but there was a relatively constant growth in the number of citations of the articles \#1, \#2, \#8 and \# 10 respectively, which covered topics related to PSM, co-production, accounting and work motivation. There was also a sharp increase in the number of citations in comparison with the previous year in articles \#3 in 2011 (8-28 citations), \#4 in 2009 (5-17 citations), and \#6 in 2011 (9-22 citations), addressing topics related to a public sector reform, shared services and public sector organizations, respectively. On the other hand, there was a dramatic reduction in the number of citations in the previous year in articles \#4 in 2011 (23-12 citations) and \#7 in 2010 (20-9 citations), which covered the topics of shared services and contracts in public services, respectively.

By analyzing the data on the most cited authors, it was noted that most research institutions to which they are linked are located in the United States (Georgia State University, George Washington University, Texas A\&M University, and the University of Wisconsin Madison) and in the United Kingdom (Cardiff University and the University of Oxford), as illustrated in Table 4.

Based on the most commonly used keywords in the articles published by the most cited authors, it was concluded that the topics of "performance" and "PSM" predominate, given that the former is covered in most articles published by six of the ten most cited authors, while the latter is the most addressed topic by four other authors. Moreover, it was observed that three of the four researchers from North American institutions conducted a great deal of their research on PSM, while the researchers linked to the United Kingdom institutions focused most of their works on public service performance.

In the analysis of the most cited authors, according to Table 4, the bibliometric indicator h-index was also considered, which measures the scientific production of a researcher. The h-index indicates the number of articles with citations that are greater than or equal to this number "h" (Hirsch, 2005). A relative connection of this indicator with the number of citations of authors was observed, 
Table 3

Data on the ten most cited articles on public service management.

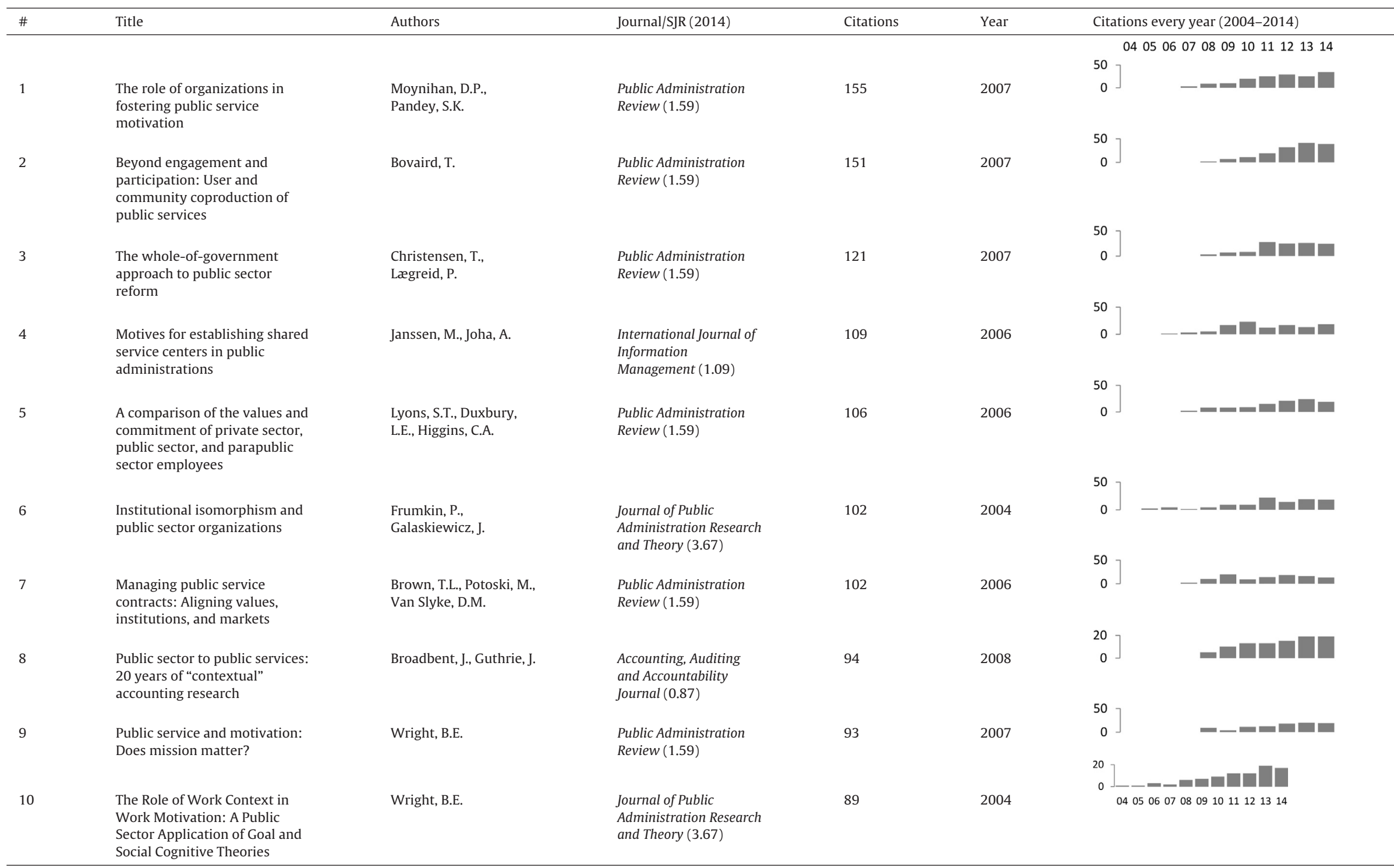




\section{Evolution of the most cited keywords}

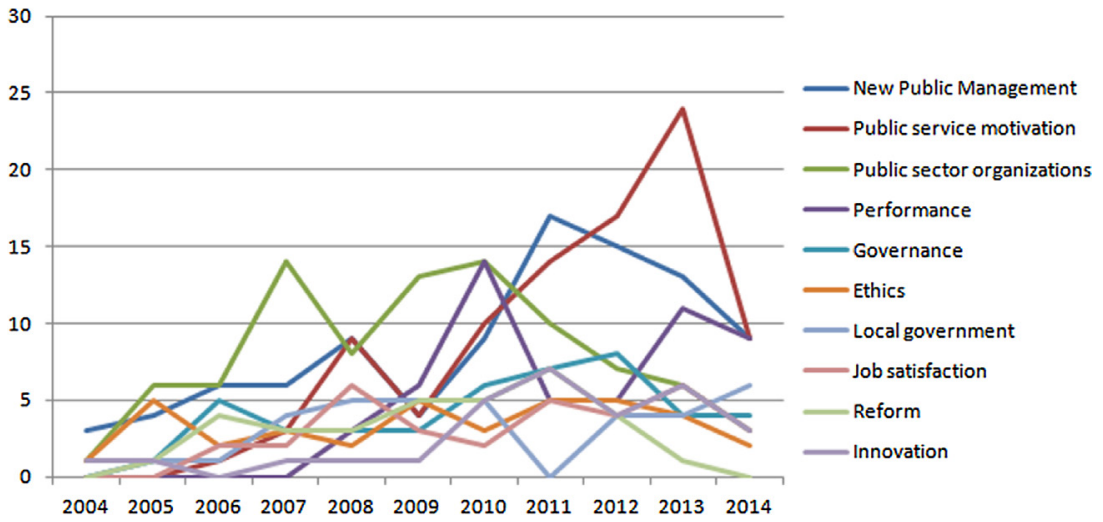

Fig. 4. Evolution of the ten most frequently used keywords.

Table 4

Data on the ten most cited authors in articles on public service management.

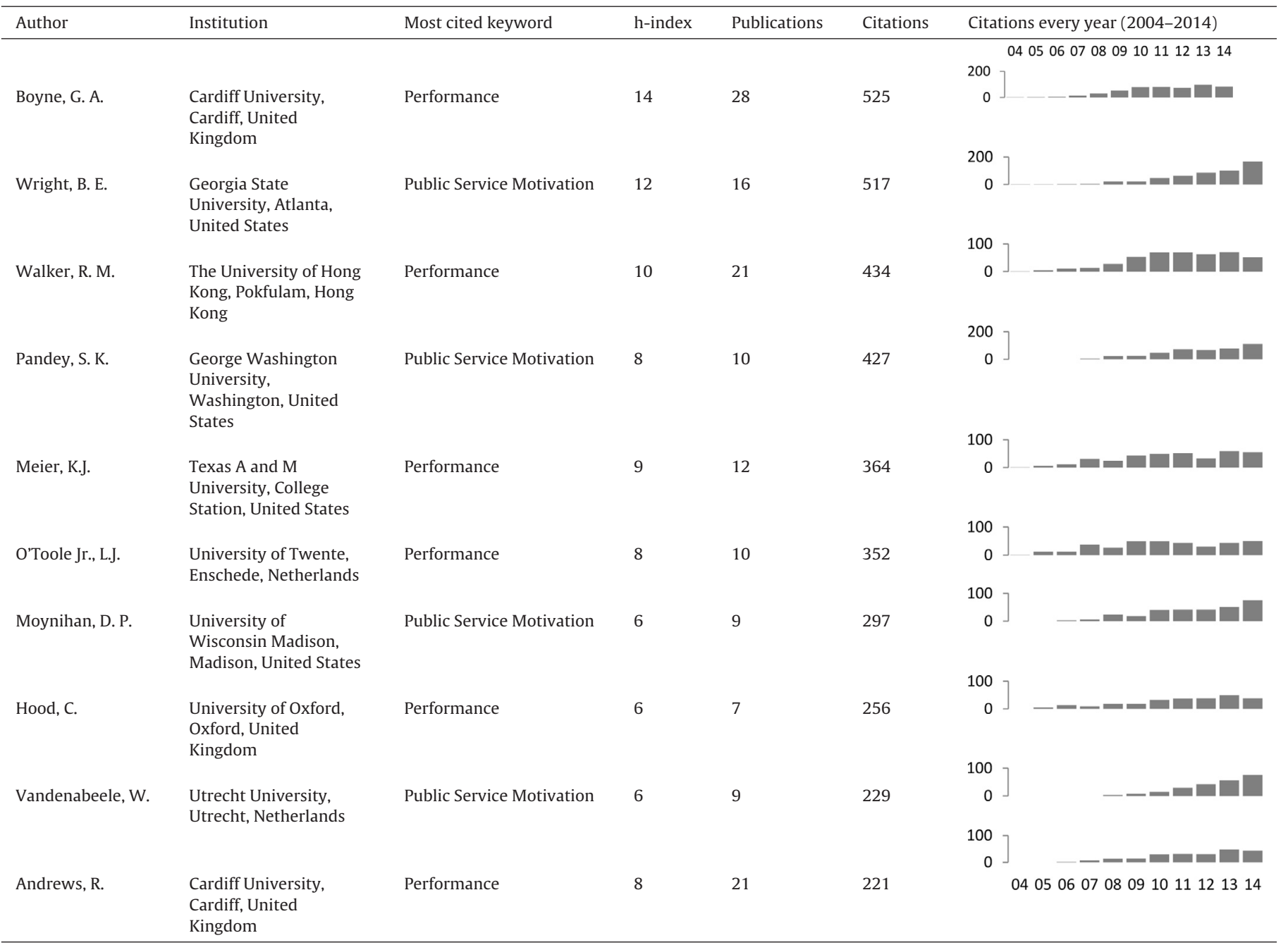

since those with the largest number of citations presented a greater h-index, except for researchers K. J. Meier and R. Andrews. The first author, although having been less cited than the researcher $\mathrm{S}$. K. Pandey, presented a greater h-index value (based on only articles about public service management). In the case of the second author, although there are fewer citations, the h-index was greater than that seen in the cases of researchers W. Vandenabeele, C. Hood and D. P. Moynihan.
Two noticeable facts regarding the number of citations of the ten most cited authors are the relatively constant growth in the number of citations in the works on public service management performed by B. E. Wright and W. Vandenabeele, and the sharp growth in the number of citations in the works of S. K. Pandey (33 citations in 2014) and B. E. Wright (67 citations in 2014) compared to the previous year. 


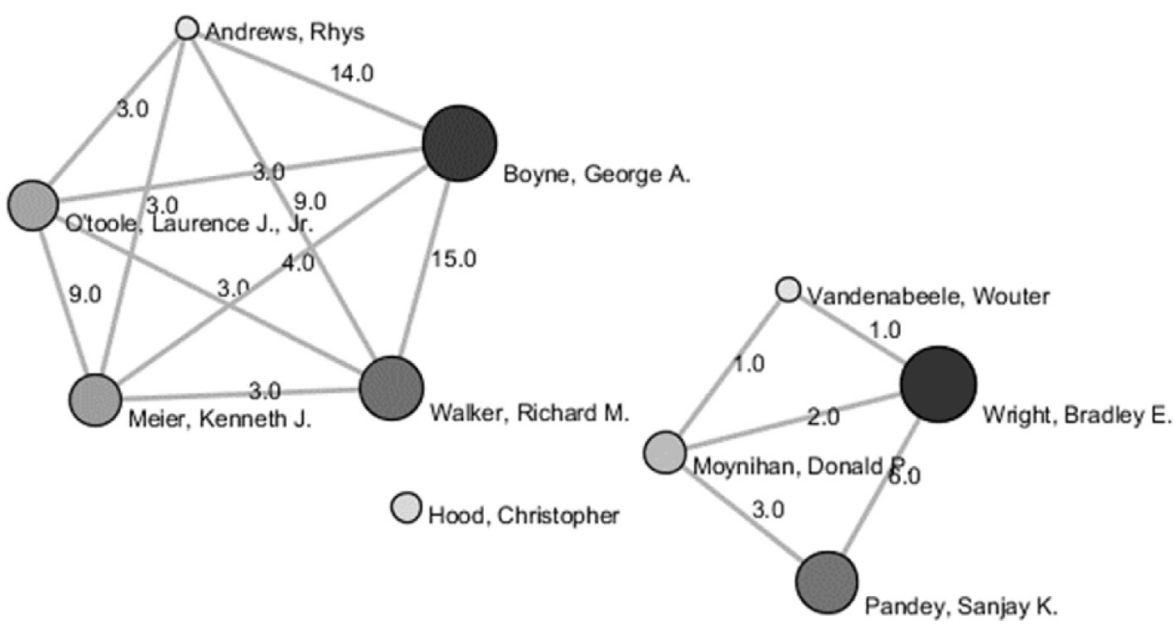

Fig. 5. Network of the ten most cited authors in articles on public service management.

After reviewing the state of research on public service management in the decade of 2004-2014, an analysis of joint publications by the most cited authors was conducted. For such a purpose, a network of authors was built, which shows that G. A. Boyne, R. M. Walker, R. Andrews, L. J. O’Toole Jr., and K. J. Meier formed a research group that was focused on the study of PSM. Accordingly, B. E. Wright, S. K. Pandey, D. P. Moynihan and W. Vandenabeele were a group of researchers who aimed their work at studying public service performance, as shown in Fig. 5. In this way, as corroborated by Table 4, it was found that the first group of researchers was mainly focused on PSM and the second one on public management performance.

\subsection{Identification of scientific gaps}

As a result of the analysis of the latest articles of the most cited authors, listed in Table 4, some scientific gaps were identified (Table 5) in order to promote and guide new studies about public service management. Thus, it was found that PSM was again the most addressed topic, being the object of four of the ten analyzed articles.

Wright, Christensen, and Isett (2013) analyzed the role of PSM in incentivizing employees in order to promote positive changes in the processes of providing public services. By using data from a survey with local government officials of a city that was reorganizing and reducing its work force, the authors concluded that only employees with greater willingness to self-sacrifice were likely to be in favor of an organizational change. Thus, the authors suggest, as future research, a longitudinal work so as to validate its findings and investigate whether the mechanisms that assist in this type of incentive differ according to the type of change.

The study conducted by Wright, Christensen, and Pandey (2013) contributes to understanding how the three different measurement dimensions of PSM (commitment to public interest, compassion and self-sacrifice) are related to one another. It was verified that, in addition to being correlated with one another, these dimensions strengthen the relation between some elements of the PSM, such as job satisfaction and work environment. Therefore, the authors propose a further investigation to confirm the effectiveness of such measures as regards their ability to predict or influence the behavior of officials.

Moynihan, Vandenabeele, and Blom-Hansen (2013) studied the flaws and opportunities of improvement in PSM, so as to validate the existing knowledge on the subject, mainly through exogenous factors. The authors suggest that future studies should be aimed at verifying its relation with explicit knowledge (documented) and tacit knowledge (intrinsic to employees).

Moreover, the work produced by Vandenabeele (2014) is based on the analysis of data collected in a survey and it objectively assesses the impact of transformational leadership on the public sector management and demonstrates that the institutional values of public organizations, represented mainly by the behavior of their supervisors, have a socializing effect on individuals and can generate benefits for PSM. In this way, the author proposes that additional works should be conducted to consolidate the survey results in different environments.

The article by Esteve, Boyne, Sierra, and Ysa (2013) focuses on the meaning that collaborative work has for public organization performance. They suggest that future studies on the topic should measure and analyze the number and intensity of collaborations in public enterprises, especially those related to education, health and safety. They also suggest that studies should be carried out to check the real influence of personal characteristics of employees on the level of cooperation in this type of business.

Walker (2013) discusses the characterization of public service management in East and Southeast Asia, and proposes more systematic and in-depth future studies on: the nature of knowledge in the region; how research affects the policy and practice of public services; how public management knowledge has evolved and changed over time; and how education can be improved through public service management.

Hood (2012) proposed and analyzed two hypotheses on performance improvement of public services: the first one is that, since not all number-based management systems are the same, performance improvement will depend on the management system being applied; the second one is that the results depend on the culture on which the number-based management system is based. The study proposed in this article suggests that this type of analysis should be performed in different social contexts and different organizations or jurisdictions.

Andrews, Boyne, Meier, O'Toole, and Walker (2012) sought to equate the vertical strategic alignment (VSA) in public organizations among the members of the senior management team and middle managers in addition to studying the influence of this alignment on public service performance. Based on the achieved results, the researchers suggest that future studies about VSA should put forward hypotheses and conduct empirical tests that are aimed at identifying management conflicts and solutions for such in order to enable prevention and/or solution, including their control mechanisms. They even propose that future works should propose new indicators to measure them. 
Table 5

Data on the latest article published by the most cited authors in public service management research.

\begin{tabular}{|c|c|c|c|c|c|}
\hline Author & Other authors & Last paper published & Year & Journal/SJR (2014) & Gap \\
\hline Boyne, G. A. & $\begin{array}{l}\text { Esteve, M., Sierra, V., } \\
\text { Ysa, T. }\end{array}$ & $\begin{array}{l}\text { Organizational collaboration in } \\
\text { the public sector: Do chief } \\
\text { executives make a difference? }\end{array}$ & 2013 & $\begin{array}{l}\text { Journal of Public } \\
\text { Administration Research } \\
\text { and Theory (3.67) }\end{array}$ & $\begin{array}{l}\text { Collaboration intensity } \\
\text { in public management } \\
\text { and influencing factors }\end{array}$ \\
\hline Wright, B. E. & $\begin{array}{l}\text { Christensen, R.K., Isett, } \\
\text { K.R. }\end{array}$ & $\begin{array}{l}\text { Motivated to Adapt? The Role } \\
\text { of Public Service Motivation as } \\
\text { Employees Face Organizational } \\
\text { Change }\end{array}$ & 2013 & $\begin{array}{l}\text { Public Administration } \\
\text { Review (1.59) }\end{array}$ & $\begin{array}{l}\text { Relation between } \\
\text { motivation and type of } \\
\text { change }\end{array}$ \\
\hline Walker, R. M. & & $\begin{array}{l}\text { Public Administration Research } \\
\text { in East and Southeast Asia - } \\
\text { Concluding Symposium } \\
\text { Remarks }\end{array}$ & 2014 & $\begin{array}{l}\text { The American Review of } \\
\text { Public Administration } \\
\text { (1.69) }\end{array}$ & $\begin{array}{l}\text { Development of public } \\
\text { administration in East } \\
\text { and Southeast Asia }\end{array}$ \\
\hline Pandey, S. K. & $\begin{array}{l}\text { Wright, B.E. } \\
\text { Christensen, R.K. }\end{array}$ & $\begin{array}{l}\text { Measuring Public Service } \\
\text { Motivation: Exploring the } \\
\text { Equivalence of Existing Global } \\
\text { Measures }\end{array}$ & 2013 & $\begin{array}{l}\text { International Public } \\
\text { Management Journal } \\
(1.46)\end{array}$ & $\begin{array}{l}\text { Expansion of PSM } \\
\text { research in number } \\
\text { and types of measures }\end{array}$ \\
\hline Meier, K.J. & & $\begin{array}{l}\text { Governance, structure, and } \\
\text { democracy: Luther Gulick and } \\
\text { the future of public } \\
\text { administration }\end{array}$ & 2010 & $\begin{array}{l}\text { Public Administration } \\
\text { Review (1.59) }\end{array}$ & $\begin{array}{l}\text { Practical issues of } \\
\text { public management }\end{array}$ \\
\hline O’Toole Jr., L.J. & $\begin{array}{l}\text { Andrews, R., } \\
\text { Boyne, G.A., } \\
\text { Meier, K. J., Walker, R. } \\
\text { M. }\end{array}$ & $\begin{array}{l}\text { Vertical strategic alignment } \\
\text { and public service performance }\end{array}$ & 2012 & $\begin{array}{l}\text { Public Administration } \\
(1.28)\end{array}$ & $\begin{array}{l}\text { Empirical tests that are } \\
\text { aimed at identifying } \\
\text { management conflicts } \\
\text { and solutions }\end{array}$ \\
\hline Moynihan, D. P. & $\begin{array}{l}\text { Vandenabeele, W., } \\
\text { Blom-Hansen, J. }\end{array}$ & $\begin{array}{l}\text { Debate: Advancing public } \\
\text { service motivation research }\end{array}$ & 2013 & $\begin{array}{l}\text { Public Money } \mathcal{E} \\
\text { Management }(0.59)\end{array}$ & $\begin{array}{l}\text { Relate self-reports } \\
\text { about PSM to } \\
\text { documented behavior }\end{array}$ \\
\hline Hood, C. & & $\begin{array}{l}\text { Public management by } \\
\text { numbers as a } \\
\text { performance-enhancing drug: } \\
\text { Two hypotheses }\end{array}$ & 2012 & $\begin{array}{l}\text { Public Administration } \\
\text { Review (1.59) }\end{array}$ & $\begin{array}{l}\text { Comparison of } \\
\text { performance tests in } \\
\text { different social } \\
\text { contexts }\end{array}$ \\
\hline Vandenabeele, W. & & $\begin{array}{l}\text { Explaining Public Service } \\
\text { Motivation - The Role of } \\
\text { Leadership and Basic Needs } \\
\text { Satisfaction }\end{array}$ & 2014 & $\begin{array}{l}\text { Review of Public } \\
\text { Personnel } \\
\text { Administration (1.45) }\end{array}$ & $\begin{array}{l}\text { Search consolidation } \\
\text { on PSM in different } \\
\text { environments }\end{array}$ \\
\hline Andrews, R. & & $\begin{array}{l}\text { Coordinating for Cohesion - } \\
\text { The Contribution of Public } \\
\text { Management to the } \\
\text { Cohesiveness of Society }\end{array}$ & 2014 & $\begin{array}{l}\text { Public Performance E } \\
\text { Management Review } \\
(0.34)\end{array}$ & $\begin{array}{l}\text { Results analysis using } \\
\text { alternative indicators } \\
\text { for cohesion }\end{array}$ \\
\hline
\end{tabular}

Andrews (2014) conducted a study on the level of optimal balance between internal management and the management related directly to citizens as a way of strengthening the connections between public organizations and the communities. He suggests, as a future study, that the result of this verification should be compared with the results of other studies using alternative indicators. These studies could be carried out by means of surveys with direct issues by the population, checking the quality of services provided by public organizations to different social classes and the degree of access that these classes have to these services.

Finally, Meier (2010) suggests the establishment of a research base for public management, which provides knowledge about how its processes take place, what the conditions of its implementation are, and how a given structure (relationships of power and infrastructure) can maximize certain sets of public management values. According to the author, the study on possibilities of public management in the future will encourage the creation of new ideas and projects aimed at practical issues.

\section{Conclusion}

Through this study, it was possible to characterize the research on public service management in the period of 2004-2014. With the analysis of the most cited keywords, it was observed that the most addressed topics mainly involve the NPM model, PSM, organizational characteristics of the sector, performance, governance, ethical aspects, local governments, job satisfaction, changes and innovation in the public sector.
The importance of PSM was confirmed in the analysis of the most cited articles, since the topic was covered in four of the ten publications with the greatest number of citations. Other noteworthy points in this analysis are that the majority of analyzed articles have a high scientific impact factor and that the journal "Public Administration Review" published six of the ten most cited articles. The yearly evolution of the number of citations of these articles was also checked, allowing the conclusion that topics related to PSM, co-production and public accountancy affairs (accounting) show a nearly steady growth.

The result of the data analysis on the most cited authors suggests that there are two groups of research on public service management that predominate in terms of publications worldwide: one located in the United States with studies that are more often aimed at public service motivation and another one located in the United Kingdom, where the majority of studies encompasses performance aspects of public service management.

Knowledge of the most cited authors and the authors' network was of paramount importance for the last analysis in this article. With that knowledge, it was possible to identify the scientific gaps indicated in the latest articles of the most cited authors, where it was found that PSM was once again the most addressed topic, being covered in four of the ten analyzed articles.

Taking into account that it was necessary to arbitrate some research parameters to be used for certain databases in order to make the implementation of this work feasible, it is possible that a few scientifically relevant articles have not been considered. However, it is worth mentioning that the present work presents, in general terms, trends and indicators of the state of research on public service management during the aforementioned period. 
The main scientific contribution of this article is to identify and systematize the knowledge generated by highly relevant scientific publications on public service management, which allowed the identification of scientific gaps that can promote and guide new studies comprising both the expansion of the existing theory and the proposition of innovative models.

Finally, its practical contribution is the identification and analysis of major works that have significantly contributed to the studied area, allowing and encouraging that its findings should be adopted by public service organizations worldwide. In this way, it is hoped that these organizations can effectively improve their processes in a continuous way and therefore meet the needs of citizens.

\section{References}

Abrizah, A., Zainab, A. N., Kiran, K., \& Raj, R. G. (2013). LIS journals scientific impact and subject categorization: A comparison between Web of Science and Scopus. Scientometrics, 94(2), 721-740. http://dx.doi.org/10.1007/s11192-012-0813-7

Andrews, R., Boyne, G. A., Meier, K. J., O’Toole, L. J., \& Walker, R. M. (2012). Vertical strategic alignment and public service performance. Public Administration, 90(1), 77-98. http://dx.doi.org/10.1111/j.1467-9299.2011.01938.x

Andrews, R. (2014). Cohesiveness of society-The contribution of public management to the cohesiveness of society. Public Performance E Management Review, 37(4), 529-545. http://dx.doi.org/10.2753/PMR1530-957637040x

Bartol, T., Budimir, G., Dekleva-Smrekar, D., Pusnik, M., \& Juznic, P. (2014). Assessment of research fields in Scopus and Web of Science in the view of national research evaluation in Slovenia. Scientometrics, 98(2), 1491-1504. http://dx.doi.org/10.1007/s11192-013-1148-8

Bovaird, T. (2007). Beyond engagement and participation: User and community coproduction of public services. Public Administration Review, 67(5), 846-860. http://dx.doi.org/10.1111/j.1540-6210.2007.00773.x

Conteh, C. (2012). Public management in an age of complexity: Regional economic development in Canada. International Journal of Public Sector Management 25(6), 464-472. http://dx.doi.org/10.1108/09513551211260649

Cuadrado-Ballesteros, B., García-Sánchez, I.-M., \& Prado-Lorenzo, J.-M. (2012). Effects of different modes of local public services delivery on quality of life in Spain. Journal of Cleaner Production, 37, 68-81. http://dx.doi.org/10.1016/j. jclepro.2012.06.008

Ercan, G., \& Cicekli, I. (2007). Using lexical chains for keyword extraction. Information Processing and Management, 43(6), 1705-1714. http://dx.doi.org/ 10.1016/j.ipm.2007.01.015

Esteve, M., Boyne, G., Sierra, V., \& Ysa, T. (2013). Organizational collaboration in the public sector: Do chief executives make a difference? Journal of Public Administration Research and Theory, 23, 927-952. http://dx.doi.org/10.1093/ jopart/mus035

Garrett, T. M., \& Sementelli, A. (2012). Knowledge production: Public management and the market spectacle. International Journal of Social Economics, 39(7), 456-473. http://dx.doi.org/10.1108/03068291211231650

Gil-Leiva, I., \& Alonso-Arroyo, A. (2007). Keywords given by authors of scientific articles in database descriptors. Journal of the American Society for Information Science and Technology, http://dx.doi.org/10.1002/asi.20595

Gomez-Jauregui, V., Gomez-Jauregui, C., Manchado, C., \& Otero, C. (2014). Information management and improvement of citation indices. International Journal of Information Management, 34(2), 257-271. http://dx.doi.org/10.1016 j.ijinfomgt.2014.01.002

Gonzalez, E., Carcaba, A., Ventura, J., \& Garcia, J. (2011). Measuring quality of life in Spanish municipalities. Local Government Studies, 37(2), 171-197. http://dx. doi.org/10.1080/03003930.2011.554826

Guerrero-Bote, V. P., \& Moya-Anegón, F. (2012). A further step forward in measuring journals' scientific prestige: The SJR2 indicator. Journal of Informetrics, 6(4), 674-688. http://dx.doi.org/10.1016/j.joi.2012.07.001

Hall, J. L. (2007). Implications of success and persistence for public sector performance. Public Organization Review, 7(3), 281-297. http://dx.doi.org/10. 1007/s11115-007-0037-0

Hirsch, J. E. (2005). An index to quantify an individual's scientific research output Proceedings of the National Academy of Sciences of the United States of America, 102(46), 16569-16572. http://dx.doi.org/10.1073/pnas.0507655102

Hood, C. (2012). Public management by numbers as a performance-enhancing drug: Two hypotheses. Public Administration Review, 72(Suppl. 1), 85-92. http://dx.doi.org/10.1111/j.1540-6210.2012.02634

Hou, Y., Ni, A. Y., Poocharoen, O., Yang, K., \& Zhao, Z. J. (2011). The case for public administration with a global perspective. Journal of Public Administration Research and Theory, 21, i45-i51. http://dx.doi.org/10.1093/jopart/muq070
Hsiao, C. H., \& Yang, C. (2011). The intellectual development of the technology acceptance model: A co-citation analysis. International Journal of Information Management, 31(2), 128-136. http://dx.doi.org/10.1016/j.ijinfomgt.2010.07. 003

Lindgren, I., \& Jansson, G. (2013). Electronic services in the public sector: A conceptual framework. Government Information Quarterly, 30(2), 163-172. http://dx.doi.org/10.1016/j.giq.2012.10.005

Meier, K. J. (2010). Governance, structure, and democracy: Luther Gulick and the future of public administration. Public Administration Review, 70(Suppl. 1), 284-291. http://dx.doi.org/10.1111/j.1540-6210.2010.02288.x

de M. Motta, P. R. (2013). O estado da arte da gestão pública. Revista de Administração de Empresas, 53(1), 82-90.

Moynihan, D. P., Vandenabeele, W., \& Blom-Hansen, J. (2013). Debate: Advancing public service motivation research. Public Money \& Management, 33(4), 288-289. http://dx.doi.org/10.1080/09540962.2013.799835

Peters, B. G., Pierre, J., \& Randma-Liiv, T. (2011). Global financial crisis, public administration and governance: Do new problems require new solutions? Public Organization Review, 11(1), 13-27. http://dx.doi.org/10.1007/s11115010-0148-X

Rashman, L., Withers, E., \& Hartley, J. (2009). Organizational learning and knowledge in public service organizations: A systematic review of the literature. International Journal of Management Reviews, 11, 463-494. http://dx. doi.org/10.1111/j.1468-2370.2009.00257.x

Soni, V. (2011). A general framework for understanding 21 st century public sector organizations. International Journal of Public Administration, 34(1-2), 76-83. http://dx.doi.org/10.1080/01900692.2011.536083

Vandenabeele, W. (2014). Explaining public service motivation: The role of leadership and basic needs satisfaction. Review of Public Personnel Administration, 34(2), 153-173. http://dx.doi.org/10.1177/0734371X14521458

Van Der Voet, J. (2014). The uniqueness and development of research methods in public administration research. Public Administration Review, 74(December), $810-813$.

Vogel, R. (2013). What happened to the public organization? A bibliometric analysis of public administration and organization studies. The American Review of Public Administration, 44(4), 383-408. http://dx.doi.org/10.1177/ 0275074012470867

Walker, R. M., Brewer, G. A., Boyne, G. A., \& Avellaneda, C. N. (2011). Market orientation and public service performance: New public management gone mad? Public Administration Review, 71, 707-717. http://dx.doi.org/10.1111/j. 1540-6210.2011.02410.x

Walker, R. M. (2013). Public administration research in East and Southeast Asia: Concluding symposium remarks. The American Review of Public Administration, 44(2), 203-209. http://dx.doi.org/10.1177/0275074013497089

Wright, B. E., Christensen, R. K., \& Isett, K. R. (2013). Motivated to adapt? The role of public service motivation as employees face organizational change. Public Administration Review, 73(5), 738-747. http://dx.doi.org/10.1111/puar.12078

Wright, B. E., Christensen, R. K., \& Pandey, S. K. (2013). Measuring public service motivation: Exploring the equivalence of existing global measures. International Public Management Journal, 16(2), 197-223. http://dx.doi.org/10. 1080/10967494.2013.817242

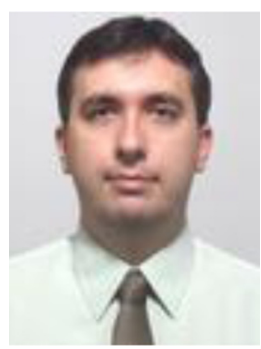

Fernando Juliani is a Bachelor of Computer Science with experience in database systems development and network management at the Institute of Aeronautics and Space, an organization which is subordinated to the Brazilian Air Force. He received the MS degree from São Paulo State University (UNESP) in 2012 and is currently a PhD candidate in the area of Optimization and Management at the same university. His research subject is the implementation of Lean Six Sigma principles in public service.

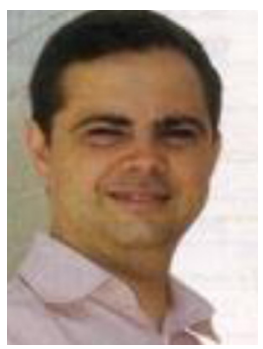

Otávio J. Oliveira is a Civil Eng., MS and PhD in Engineering. $\mathrm{He}$ is an Associate Professor at São Paulo State University (UNESP). He is the coordinator of the Production Engineering Post Graduation Program at UNESP, Guaratinguetá campus. His line of research encompasses Quality and Environment Management, mainly ISO 9001, ISO 14001 and Lean Six Sigma. 